\title{
Ogólnopolska Konferencja Naukowa „Opiekun - Wychowawca - Nauczyciel. Między powinnością a (nie)możnością (konteksty historyczne i współczesne)"
}

W dniach 18 i 19 maja 2011 r. w Ustce odbyła się Ogólnopolska Konferencja Naukowa zorganizowana przez Instytut Pedagogiki Akademii Pomorskiej w Słupsku. Temat konferencji brzmiał: „Opiekun - Wychowawca - Nauczyciel. Między powinnością a (nie) możnością (konteksty historyczne i współczesne)". Honorowy patronat nad konferencją objęły władze regionu słupskiego - Prezydent Miasta Słupska oraz Burmistrz Miasta Ustki.

Uczestnikami konferencji byli przedstawiciele świata nauki z ośrodków akademickich całej Polski: pedagodzy, historycy, psycholodzy, prawnicy, socjolodzy, pracownicy służby zdrowia, ekonomiści, nauczyciele, opiekunowie, wychowawcy - praktycy i teoretycy oraz studenci Akademii Pomorskiej.

Konferencja obejmowała dwudniową sesję plenarną oraz cztery sekcje tematyczne rozpatrujące następujące grupy problemów:

I - Nauczyciel - Wychowawca - Opiekun w perspektywie historycznej;

II - Współczesny nauczyciel. Między powinnością a (nie)możnością;

III - Dylematy pracy dydaktycznej i opiekuńczo-wychowawczej a wymagania wobec nauczyciela;

IV - Przygotowanie nauczyciela do wymagań zglobalizowanego społeczeństwa.

Szczególnie cenionym przez prelegentów i zaproszonych gości aspektem obrad była ich interdyscyplinarność.

Uroczystego otwarcia konferencji dokonał Rektor Akademii Pomorskiej w Słupsku prof. dr hab. Roman Drozd.

Obrady plenarne przebiegające w pierwszym dniu konferencji prowadziła prof. dr hab. Ewa Bilińska-Suchanek. Prelegenci wygłosili referaty poruszające problematykę dotyczącą opiekuna, nauczyciela i wychowawcy na przestrzeni dziejów. Dokonywano analizy ich sytuacji społecznej, ekonomicznej, politycznej, edukacyjnej, zawodowej. W wypowiedziach podkreślano znaczenie w pracy edukacyjnej, wychowawczej i opiekuńczej dyspozycji osobowościowych nauczyciela, opiekuna i wychowawcy, merytorycznego ich przygotowania oraz ukazano efekty ich pracy przejawiające się w postawach i zachowaniach wychowanków, a nawet w różnorodnych formach komunikacji werbalnej młodego pokolenia.

Prof. dr hab. E. Bilińska-Suchanek (Akademia Pomorska) poruszyła problem kreatywności nauczyciela w aspekcie cechy własnej, stanu umysłu, zabezpieczenia indywidualnej wolności oraz porządku społecznego. Kolejny wykład wygłosiła prof. dr hab. K. WróbelLipowa (UMCS Lublin), która zapoznała słuchaczy z działalnością nauczyciela-opiekuna polskich „dzieci tułaczy” w czasie II wojny światowej. Prof. dr hab. K. Puchowski (Uniwersytet Gdański) wspólnie z doktorantką UG mgr Lucyną Roll, pozostając w nurcie historii wychowania, w sposób nie tylko ciekawy, ale także dowcipny zaprezentował uczestnikom konferencji postać nauczyciela savoir-vivre’u Barona Adolpha Franza Fredracha 
Knigge. Zagadnienia związane ze skutkami niewłaściwie prowadzonej edukacji i wychowania w kontekście komunikacji werbalnej zaprezentowała prof. dr hab. Wanda Woronowicz (Akademia Pomorska) w wystąpieniu pt. „Okaleczony język młodego pokolenia”. Kolejny prelegent prof. dr hab. Lucyna Preuss-Kuchta (Akademia Pomorska) omówiła pozytywistyczne komponenty edukacji szkolnej, podkreślając konieczność podjęcia próby godzenia interesów uczniów i nauczycieli w procesie szeroko pojętej edukacji. Prof. dr hab. A. Kusztelak (Uniwersytet Przyrodniczy w Poznaniu) zaprezentował postać nauczyciela XXI w. Rozwój duchowy nauczyciela w kontekście poglądów Marii Montessori przedstawiła w swoim wystąpieniu prof. dr hab. J. Kruk (Elbląska Uczelnia Humanistyczno-Ekonomiczna). Natomiast prof. dr hab. R. Tomaszewski (Akademia Pomorska) w swym wykładzie zajął się nauczycielem akademickim w XX i XXI w., jego problemami, możliwościami i ograniczeniami. Ostatnim wystąpieniem w sesji plenarnej był wykład prof. dr hab. J. Karbowniczek (Wyższa Szkoła Filozoficzno-Pedagogiczna „Ignatianum”w Krakowie), która przybliżyła słuchaczom postać nauczyciela z pasją.

W sekcji pierwszej, której przewodniczyli prof. dr hab. K. Puchowski i prof. dr hab. K. Wróbel-Lipowa głos zabrało 9 prelegentów. Dr J. Szady (Katolicki Uniwersytet Lubelski) podjęła refleksję na temat nauczyciela szkoły parafialnej w XVI-XVIII w. W kręgu zbliżonej tematyki pozostawały dwa kolejne wystąpienia. Mgr Tomasz Fetzki (Łużycka Wyższa Szkoła Humanistyczna Żarach) omówił trudną pracę nauczyciela - pedagoga specjalnego od E. Seguina po współczesne czasy. Natomiast dr Danuta Apanel (Akademia Pomorska) zaprezentowała zmienność ról i zadań nauczyciela ucznia niepełnosprawnego na przestrzeni XX w. Kolejna prelegentka mgr Marcelina Knop (Uniwersytet Warmińsko-Mazurski w Olsztynie) przedstawiła postać wychowawcy - nauczyciela w poglądach pedagogicznych Marceliny Darowskiej w ujęciu historycznym oraz współczesnym na przykładzie Prywatnego Liceum Ogólnokształcącego Sióstr Niepokalanek w Szymonowie. Kondycję zawodową nauczycieli w dziesięcioleciu powojennym 1945-1955 w województwie lubelskim omówiła dr Joanna Bugajska-Więcławska (UMCS Lublin). Trudną i skomplikowaną sytuację nauczycieli szkoły średniej ogólnokształcącej w Polsce w latach 80. zaprezentowała dr Justyna Gulczyńska (UAM Poznań). Kolejny prelegent dr Henryk Porożyński (Akademia Pomorska) zapoznał słuchaczy z funkcjonowaniem szkolnictwa w Chojnicach oraz z wybitnymi nauczycielami, opiekunami i wychowawcami pracującymi w przeszłości w tym mieście. Natomiast mgr Waldemar Sypiański (Akademia Pomorska) zaprezentował uwarunkowania nauczania w polskiej szkole języków obcych w przeszłości i obecnie. Ostatnia prelegentka mgr Małgorzata Kowalczyk (Akademia Pomorska) omówiła działalność nauczycieli uniwersytetów III wieku w latach 1971-2011.

Sekcja II obradowała pod kierunkiem prof. dr. hab. A. Kusztelaka i dr. W. Wrześniewskiego. Zaprezentowano 16 referatów. Dr Tomasz Skonieczny (Akademia Pomorska) omówił rolę Centrum Edukacji Nauczycieli w Koszalinie w inspirowaniu nauczycieli do samokształcenia i samodoskonalenia. Dr Maria Aleksandrovich (Akademia Pomorska) scharakteryzowała wyzwania psychologiczno-pedagogiczne w edukacji uczniów zdrowych. Dr Wincenty Wrześniewski (Uniwersytet Przyrodniczy w Poznaniu) przedstawił nauczyciela w roli biurokraty, mgr Madalena Franiel (Uniwersytet Śląski) zaprezentowała 
nauczyciela jako realizatora indywidualizacji w procesie kształcenia. W kręgu zbliżonej tematyki pozostawały dwa wystąpienia: dr. Andrzeja Laskowskiego (Akademia Pomorska), który mówił o roli i osobowości nauczyciela - wychowawcy oraz dr Agnieszki Łagody (Akademia Pomorska), która omówiła istotę zawodu współczesnego „dobrego” nauczyciela. Zagadnienia związane z trudną rolą nauczyciela klas młodszych podejmowali następujący prelegenci: dr Lucyna Maksymowicz (Akademia Pomorska), dr Barbara Pietrzak-Szymańska (Wyższa Szkoła Pedagogiczna TWP w Warszawie), mgr Milena Sochocka (Uniwersytet Warmińsko-Mazurski w Olsztynie), dr Jolanta Maciąg (Akademia Pomorska). Dr Agnieszka Zalewska-Meler (Akademia Pomorska) oraz dr Anna Rożnowska (Politechnika Koszalińska) zaprezentowały problematykę związaną z rolą nauczyciela w promocji zdrowia. Kompetencje ekologiczne nauczycieli w kształtowaniu postaw uczniów wobec przyrody omówiła mgr Małgorzata Chrzanowska (Akademia Pomorska). Dr Ewa Murawska (Akademia Pomorska )zaprezentowała perspektywę nauczycielskiej codzienności i niecodzienności, a mgr Marta Sałapata (Akademia Pomorska) przedstawiła przestrzenie wpływające na jakość pracy zawodowej nauczyciela.

W sekcji III, której przewodniczyły prof. dr hab. Wanda Woronowicz i dr Grażyna Durka, w 15 wystąpieniach poruszano trudne zagadnienia związane z pracą dydaktyczno-wychowawczą nauczyciela w świetle wymagań, jakie się jemu obecnie stawia. Obrady otworzył referat dr. Lesława Lesnera (Akademia Pomorska w Słupsku), który przedstawił wybrane problemy odpowiedzialności prawnej nauczyciela - wychowawcy - opiekuna. W kolejnej prezentacji dr Anetta Jaworska (Akademia Pomorska w Słupsku) zwróciła uwagę na trudne zadania, jakie stoją przed wychowawcą w obliczu instytucjonalnych form resocjalizacji. Z referatem tym korespondowało wystąpienie dr Grażyny Durka (Akademia Pomorska w Słupsku) rozważającej kwestie stanowiska nauczyciela wobec agresji ucznia. Opinię rodziców i nauczycieli na temat opieki i wychowania w szkole przedstawiła dr Iwona Gumowska (Akademia Pomorska w Słupsku). Następnie mgr Andrzej Maślak (Akademia Pomorska w Słupsku) dokonał charakterystyki Opiekuna XXI w. Dr Małgorzata Słowik (Akademia Pomorska w Słupsku) wskazała kontrowersje, jakie towarzyszą projektowi ustawy o wspieraniu rodziny i sprawowaniu pieczy zastępczej. Ciekawą problematykę dotyczącą języka obcego w kontekście terra cognita czy terra incognita zaprezentowała dr Małgorzata Jarecka-Żylak (Akademia Pomorska w Słupsku). Dr Marianna Powałka dokonała analizy wzajemnych oczekiwań uczniów i nauczycieli gimnazjów. Jak ważny w pracy opiekuńczo-wychowawczej jest profesjonalizm, wskazała mgr Magdalena Zmysłowska (Uniwersytet Warmińsko-Mazurski w Olsztynie), odwołując się do porównania realiów z możliwościami owego profesjonalizmu. Istotne z perspektywy współczesnego tak intensywnie rozwijającego się świata techniki jest zagadnienie poruszone przez mgr Monikę Frania (Uniwersytet Śląski w Katowicach). Autorka ukazuje kwestię znaczenia mediów w życiu młodzieży szkolnej w kontekście zadań edukacji medialnej stawianych współczesnemu nauczycielowi-wychowawcy. Z referatem tym koresponduje prezentacja mgr. Mateusza Nitka (Akademia Pomorska w Słupsku), w którym autor porusza problematykę dotyczącą kompetencji informacyjnych nauczyciela w świecie sieci. Mgr Walentyna Pasieka (Akademia Pomorska w Słupsku) ukazała jakże ważną rolę nauczyciela w rozwijaniu umiejętności społecznych dzieci i młodzieży zagro- 
żonych wykluczeniem społecznym. Referat mgr Anny Babickiej (Akademia Pomorska w Słupsku) wskazał, jak dużą rolę odgrywa właściwa postawa nauczyciela wobec autoekspresji ucznia. Refleksje nauczyciela wobec egzaminu zawodowego w zawodzie technik-informatyk scharakteryzował mgr inż. Henryk Prus (Uniwersytet Warmińsko-Mazurski w Olsztynie). Mgr Joanna Król-Mazurkiewicz (Akademia Pomorska w Słupsku) rozważała kwestie, czy efektywne uczenie się jest możliwe tylko w symbiozie nauczyciel - uczeń.

Sekcja IV, której moderatorkami były prof. dr hab. Jolanta Kruk oraz prof. dr hab. Lucyna Prauss-Kuchta, rozważała problematykę przygotowania nauczyciela do zadań, jakie stawia przed nim zglobalizowane społeczeństwo. Zagadnieniom tym poświęcono 16 wystąpień. Różne aspekty nowych wyzwań stojących przed uczelniami kształcącymi przyszłych nauczycieli przedstawili: mgr Karolina Zaniewska i mgr Michalina Czaja (Akademia Pomorska w Słupsku), dr Beata Lukasik (Akademia im. Jana Długosza w Częstochowie), dr Wacław Adamiak (Państwowa Wyższa Szkoła Zawodowa w Głogowie) oraz dr Mariusz Ausz (UMCS Lublin), który skupił się na roli praktyk w przygotowaniu zawodowym nauczyciela. Badania dotyczące postrzegania różnych elementów funkcjonowania nauczyciela, widzianych z perspektywy studentów pedagogiki, zaprezentowali dr Iwona Zychowicz i mgr Piotr Modzelewski (Akademia Pomorska w Słupsku). Tematyki roli ekspresji artystycznej w procesie dydaktyczno-wychowawczym dotyczyły wystąpienia dr Małgorzaty Puchowskiej (Uniwersytet Gdański) i dr Moniki Adamskiej-Staroń (Akademia im. Jana Długosza w Częstochowie). Dr Zbigniew Meger (Akademia Pomorska w Słupsku) zaprezentował problematykę zmieniającej się roli nauczyciela w warunkach przeobrażeń technologicznych. Dr Robert Parol (Akademia Pomorska w Słupsku) omówił zagadnienie przygotowania terapeutów pracujących z osobami skazanymi na karę pozbawienia wolności, zaś mgr Przemysław Juszczykowski (Akademia Pomorska w Słupsku) mówił o przygotowaniu zawodowym animatorów czasu wolnego. Wystąpienie mgr. Karola Wiszniewskiego (Akademia Pedagogiczna w Słupsku) dotyczyło wykorzystania w procesie dydaktyczno-wychowawczym dalekowschodnich sztuk walki. Mgr Izabela Stelmasiak (Akademia Pedagogiczna w Słupsku) poruszyła problematykę kształcenia osób z pogranicza kulturowego, zaś mgr Małgorzata Siupik (Akademia Pedagogiczna w Słupsku) omówiła wizerunek nauczyciela, jaki prezentowany jest we współczesnej kinematografii.

W drugim dniu konferencji podczas obrad plenarnych moderatorzy poszczególnych sekcji tematycznych dokonali podsumowań prowadzonych w sekcjach obrad i, burzliwych często, dyskusji.

W podsumowaniu prof. dr hab. Ewa Bilińska-Suchanek podziękowała wszystkim prelegentom za tak cenne i wszechstronnie poruszane zagadnienia dotyczące szeroko rozumianej problematyki pedentologicznej.

Danuta Apanel

Justyna Gulczyńska

Tomasz Fetzki 